\title{
Disposal Pattern of Honey in Western Ghats of Karnataka, India
}

\author{
K. Anil Kumar ${ }^{1 *}$ and D. H. Mitrannavar ${ }^{2}$ \\ University of Agricultural Sciences Dharwad, Karnataka, India \\ *Corresponding author
}

A B S T R A C T

\section{Keywords}

Beekeeper, Honey, Marketing cost, Marketing channels, Price spread

\section{Article Info}

Accepted:

17 August 2020 Available Online:

10 September 2020
Honey is natural substance which having multiple benefits and it was produced by bees from flower nectars. Honey has enormous demand, and it can be produced by putting fewer efforts, the study was conducted to investigate the marketing management of honey in India. India stands in one of the top producing country in world but it has highly unorganized marketing facilities. The most of beekeepers depends on cooperative societies and food companies in marketing of honey. The beekeeper was hardly spending on an average of Rs.43 on every kilogram of honey as marketing cost, and price spread was higher than 30 percent. Indian honey having great demand in international market, if beekeepers engage in directly exporting honey to international market, that will become major structural transformation in marketing of honey.

\section{Introduction}

Beekeeping is one of the best subsidiary enterprises for farmer to enhance farm income through fewer efforts. In fact, the successful beekeeper acquired lot of skills in handling bees and understanding behavior and needs of hive. In India, the climate is very supportive and presence of enormous flower source is attracting beekeeping as a potential enterprise. India is in positive direction in production and many supporting programmes on skill development and financial help was given to farmers to increase honey production in India and those programmes was certainly bring change in honey production. when it comes to marketing, India doesn't have any organized market even government and research institutes was not come up with any marketing support through establishing procurement centers. Honey market still remained as highly unorganized and having high price range across different places. This study attempting to give clear picture of marketing decisions of beekeepers, various stakeholders participating in marketing of honey and their impact and opportunities honey marketing in India. 


\section{Materials and Methods}

The study was taken in Uttara Kannada district which is one of leading honey producing district in Karnataka as per (Secondary data/information collected from ) the records of Forestry Department. The 120 beekeepers including both stationary and migratory beekeepers were selected. The primary data pertaining to disposal pattern, marketing cost, post harvest operation and pricing strategy was collected from beekeepers by using pre-tested and well structured schedule through personal interview method. The tabular analysis was used in determining price spread, marketing cost and marketing channels

\section{Results and Discussion}

From the study, researcher identified few marketing channels viz.

Channel - I Beekeeper $\rightarrow$ Village Level Trader $\rightarrow$ Wholesaler $\rightarrow$ Retailer $\rightarrow$ Consumer

Channel-II Beekeeper $\rightarrow$ Cooperative Society $\rightarrow$ Consumer

Channel-III Beekeeper $\rightarrow$ Food Retail Companies $\rightarrow$ Consumer

Channel-IV Beekeeper $\rightarrow$ Consumer

The honey was disposed off in above four marketing channels. Out of 120 beekeepers, eight beekeepers were selling honey through Channel-I which accounts for only 6 percent and the average quantity of honey sold in this channel was $482.25 \mathrm{~kg}$ per year per beekeeper. Forty-two beekeepers from 120 sample beekeepers using Channel-II and which accounts for 35 per with average quantity of honey sold in this channel was $541.20 \mathrm{~kg}$ per annum per beekeeper. Twenty four beekeepers were selling honey through Channel-III and it accounts for 20 percent with average quantity sold in this channel was
$750.79 \mathrm{~kg}$ per year per beekeeper. And finally, 46 beekeepers selling honey through Channel-IV and it accounts for 38 percent with an average quantity of honey sold in this channel was $1254.38 \mathrm{~kg}$ per year per beekeeper.

\section{Marketing cost incurred for beekeeper in the marketing of honey in different channels}

The marketing costs including packaging, labeling, processing, transportation and goods tax incurred by beekeepers in selling of different marketing channel were presented in Table 1. The results showed that, the marketing cost incurred for beekeepers was varied from one marketing channel to others. The marketing cost of beekeepers in the Channel-I was ₹ 37 per $\mathrm{kg}$ of honey. The major components were labor cost accounts for 40.54 percent ( $₹ 40.54$ ) processing cost accounts for 32.43 percent ( $₹ 12$ ), and Miscellaneous cost accounts for 27.02 percent (₹ 10).

In Channel-II, the total marketing charges were ₹ 43 per $\mathrm{kg}$ of honey. The major components were labor cost accounts for 34.88 percent ( $₹ 15 / \mathrm{kg}$ ), processing cost accounts for 27.90 percent (₹12/kg), miscellaneous cost accounts for 23.25 percent (₹ 10/kg) and transportation cost 24.19 percent (₹ 6/kg)

In Channel-III, the total marketing cost incurred for beekeeper was ₹ 62 per $\mathrm{kg}$. Labor cost, transportation, and miscellaneous cost and processing cost accounts for 32.25 percent, 24.19 percent, 24.19 percent, and 19.35 percent respectively.

In Channel-IV, the beekeeper has to spend more on marketing because the beekeepers sold honey directly to consumers. The total marketing cost was ₹ 71.3 per kg of honey. it 
includes 35.06 percent of labor cost, 21.03 percent of processing cost, 10.51 percent of packaging cost, 5.38 percent of labeling cost and 28.05 percent of the miscellaneous cost.

The price spread in the marketing of honey in different marketing channels in the study area

The price spread is difference between the producers' selling price and consumer's purchase price. The price spread helps to calculate the producer's share in consumer's rupee. This indicates the share of price received by producer in consumer's purchase price. The price spread and producer's share in consumer's rupee was presented in Table 2 .

\section{Channel-I}

In Channel-I, the producer share in consumer rupee was 70 percent. The beekeeper sold honey to the village level trader in the rate of $₹ 350$ per $\mathrm{kg}$ of honey. Out of ₹ 350, the marketing cost incurred for beekeeper was ₹37 per $\mathrm{kg}$ and a net price realized for beekeeper was $₹ 313$ per $\mathrm{kg}$. At the next level, the village level trader sold honey at the rate of ₹ 450 per $\mathrm{kg}$ of honey to the wholesaler with a marketing cost of ₹ 65.5 per $\mathrm{kg}$ of honey and profit margin of ₹ 34.5 per $\mathrm{kg}$ of honey. The wholesaler sells to retailers at a rate of $₹ 475$ per $\mathrm{kg}$ of honey with marketing cost of ₹ 15 per $\mathrm{kg}$ and marketing margin of ₹ 10 per kg. Finally, the retailer sells honey to consumers for ₹ 500 per $\mathrm{kg}$ of honey after marketing cost of ₹ 5 per kg and marketing margin of ₹ 20.

\section{Channel-II}

In Channel-II, the producer share in consumer rupee was 77.77 percent. In this channel, the beekeeper sells honey to cooperative society for the price of ₹ 350 per $\mathrm{kg}$ after meeting marketing cost of ₹ 43 per kg of honey and a net price realized for beekeeper was ₹ 313 per $\mathrm{kg}$ of honey. In the next level, the cooperative society processes the honey and sells to consumers at the price of ₹ 450 per kg after meeting the marketing cost of 67.80 and the marketing margin of ₹ 32.20 per kg of honey.

\section{Channel-III}

In Channel-III, the producer share in consumer rupee was 63.63 percent. In this channel, the beekeepers sell their produce to food retail companies at the rate of ₹ 350 per $\mathrm{kg}$ of honey. The beekeeper incurred marketing cost of ₹ 62 per kg of honey and a net price realized was ₹ 288 per $\mathrm{kg}$ of honey. The food retail companies process and packed it and sold in company outlets for consumers at a price of ₹ 550 per $\mathrm{kg}$ of honey. The marketing cost incurred for the company was $₹ 79.5$ per kg of honey and marketing margin of ₹ 120.5 per kg of honey.

\section{Channel-IV}

In this channel, the producer share in consumer rupee was 100 percent because in this channel the beekeeper sells honey directly to the consumer with their own rand and price. In this channel, most of the beekeeper sells honey at the rate of ₹ 400 per $\mathrm{kg}$ to consumers. The marketing cost incurred for beekeeper was ₹ 71.30 per $\mathrm{kg}$ and a net price realized was $₹ 328.70$ per $\mathrm{kg}$ of honey.

From the study many interesting facts on marketing of honey in Western Ghats of Karnataka and few discussed in detailed. First of all, the price of honey is decided by nature of beekeeping that includes, if stationary beekeeper, the maintains cost will be comparatively less and production also less hence and source is known certainly, in western Ghats, we found enormous medicinal flowers so, by considering all these factors they sell at higher prices in personal contacts 
and for relatives. When it comes to migratory beekeepers, the number of bee hives will be high and reduce competition and increase productivity in transfer hives to floral potential plain land and it increase cost of production at the same time the productivity also better. This category of beekeepers sells their honey to cooperative societies, food companies and selling at their own retail shops. Here customer base is huge and unknown. In this process the price was comparatively less. Along with these two categories of beekeepers we found rock bee hunters. This was inheriting profession for particular category of tribal people and after named as Jeenu Kuruba but currently the number of active families was reduced. This category of people was expertise in hunting rock bee hives which located in deep forest and highly rugged rocks. This is done in certain period especially in spring seasonal they end up with huge honey and wax in small time period. Hence, the rock bee honey was rich in pollen and medicinal properties. But during harvesting, hunters squeeze the brood. It leads to high wax content in honey. during this period the honey is abundantly available in the hence people find surplus supply it leads to less price for rock bee honey.

The choosing of marketing channels by beekeepers was influenced by many factors such as the occupation of farmer/beekeeper, number of hives or scale of operation, family size, land holdings and passion of beekeeping.

Table.1 Marketing cost incurred by beekeeper in marketing of honey in different channel

\begin{tabular}{|c|c|c|c|c|c|c|c|c|c|}
\hline \multirow{2}{*}{$\begin{array}{l}\text { Sl. } \\
\text { No. }\end{array}$} & \multirow[t]{2}{*}{ Particulars } & \multicolumn{2}{|c|}{ Channel I } & \multicolumn{2}{|c|}{ Channel II } & \multicolumn{2}{|c|}{ Channel III } & \multicolumn{2}{|c|}{ Channel IV } \\
\hline & & $\begin{array}{l}\text { Amount } \\
(₹ / \mathrm{kg})\end{array}$ & $\%$ & $\begin{array}{l}\text { Amount } \\
(₹ / \mathrm{kg})\end{array}$ & $\%$ & $\begin{array}{l}\text { Amount } \\
\text { (₹/kg) }\end{array}$ & $\%$ & $\begin{array}{l}\text { Amount } \\
\text { (₹/kg) }\end{array}$ & $\%$ \\
\hline 1 & Processing & 12.00 & 32.43 & 12.00 & 27.90 & 12.00 & 19.35 & 15.00 & 21.03 \\
\hline 2 & $\begin{array}{l}\text { Packaging } \\
\text { material }\end{array}$ & 0 & 0 & 0 & 0 & 0 & 0 & 7.50 & 10.51 \\
\hline 3 & $\begin{array}{l}\text { Labeling } \\
\text { material }\end{array}$ & 0 & 0 & 0 & 0 & 0 & 0 & 3.80 & 5.32 \\
\hline 4 & Labor charges & 15.00 & 40.54 & 15.00 & 34.88 & 20.00 & 32.25 & 25.00 & 35.06 \\
\hline 5 & Transportation & 0 & & 6.00 & 13.95 & 15.00 & 24.19 & 0 & 0 \\
\hline 6 & Miscellaneous & 10.00 & 27.02 & 10.00 & 23.25 & 15.00 & 24.19 & 20.00 & 28.05 \\
\hline & Total & 37.00 & 100 & 43.00 & 100 & 62.00 & 100 & 71.30 & 100 \\
\hline
\end{tabular}


Table.2 The price spread in different marketing channels in marketing of honey

\begin{tabular}{|c|c|c|c|c|c|}
\hline Sl. No. & Particulars & Channel I & Channel II & Channel III & Channel IV \\
\hline \multirow[t]{4}{*}{1} & \multicolumn{5}{|l|}{ Producer } \\
\hline & Price received & 350 & 350 & 350 & 400 \\
\hline & Marketing cost & 37 & 43 & 62 & 71.3 \\
\hline & Net price realized & 313 & 307 & 288 & 328.70 \\
\hline \multirow[t]{5}{*}{2} & \multicolumn{5}{|c|}{ Village level honey collector } \\
\hline & Purchase price & 350 & - & - & - \\
\hline & Marketing cost & 65.5 & - & - & - \\
\hline & Sale price & 450 & - & - & - \\
\hline & Marketing margins & 34.5 & - & - & - \\
\hline \multirow[t]{5}{*}{3} & \multicolumn{5}{|l|}{ Cooperative society } \\
\hline & Purchase price & - & 350 & - & - \\
\hline & Marketing cost & - & 67.8 & - & - \\
\hline & Sale price & - & 450 & - & - \\
\hline & Marketing margins & - & 32.2 & - & - \\
\hline \multirow[t]{5}{*}{4} & \multicolumn{5}{|l|}{ Food retailers } \\
\hline & Purchase price & - & - & 350 & - \\
\hline & Marketing cost & - & - & 79.5 & - \\
\hline & Sale price & - & - & 550 & - \\
\hline & Marketing margins & - & - & 120.5 & - \\
\hline \multirow[t]{5}{*}{5} & \multicolumn{5}{|l|}{ Wholesaler } \\
\hline & Purchase price & 450 & & & \\
\hline & Marketing cost & 15 & & & \\
\hline & Sale price & 475 & & & \\
\hline & Marketing margins & 10 & & & \\
\hline \multirow[t]{5}{*}{6} & \multicolumn{5}{|l|}{ Retailer } \\
\hline & Purchase price & 475 & & & \\
\hline & Marketing cost & 5 & & & \\
\hline & Sale price & 500 & & & \\
\hline & Marketing margins & 20 & & & \\
\hline \multirow[t]{3}{*}{7} & Consumer price & 500 & 450 & 550 & 400 \\
\hline & Price spread & 150 & 100 & 200 & $\mathbf{0}$ \\
\hline & $\begin{array}{l}\text { Producers share in } \\
\text { consumers rupee }\end{array}$ & $70 \%$ & $77.77 \%$ & $63.63 \%$ & $100 \%$ \\
\hline
\end{tabular}


The beekeepers, those adopted honey production as a subsidiary enterprise were small family size and more landholdings hence they spend more time on crops rather than honey production, therefore, most probably these beekeepers choose to sell honey to village level trader after meeting family consumption and this beekeepers usually follow stationary beekeeping with less number of beehives. In the second stage, the village level trader pool the small quantities of honey from remote areas and small beekeepers and later process and packed it in their own brand name and distributed to wholesalers and retailers and ultimately honey reaches to consumers

Sometimes the beekeepers register membership in beekeeping cooperative societies to utilize financial and technical benefits from society in such cases, beekeeper sells honey to cooperative society for pre-fixed price. In this case, also, the beekeepers would have adopted honey production as a subsidiary enterprise and usually, they focused on other main incomegenerating occupation. In the later part of the marketing process, the cooperative society would process and packed it in the name of a cooperative society. Sometimes cooperative society sells honey directly to consumers through their own marketing outlets or distributed to other retailers.

Apart from village level traders and cooperatives, the food retail companies also play a role in the marketing of honey. The companies such as Dabur India limited and Patanjali Ayurved Limited procure honey from beekeepers through their procurement units and pooled and processed and sold in their brand name. The beekeepers sell honey for higher prices only after met company standards of honey.

In some cases, beekeepers sell honey directly to consumers. The beekeeper was well recognized in providing quality honey and sometimes they provide freshly harvested honey in front of consumers only. But those beekeepers usually charge comparatively higher prices than other retail shops or cooperatives societies. This kind of honey marketing was comparatively popular after marketing through cooperatives.

\section{Marketing cost of beekeepers in marketing of honey in Western Ghats}

The marketing cost incurred for beekeeper was varied from channel to channel and sometimes it depends on the number of beehives rearing. In channel-I, the beekeeper has to spend ₹ 37per $\mathrm{kg}$. In this cost major components were, processing cost ( $₹ 12 / \mathrm{kg}$ ) and labor cost (₹15/kg). in this channel, the beekeeper should do with primary processing which includes filtering to remove pollen and wax fragments and should be dried in sunlight or by using warm water to bring lower moisture level to prevent adulteration; for this, the beekeeper has to spend labor either it may be family labor or temporary labor.

In channel II, the beekeeper has to spend same as in channel but in this, the beekeeper should carry honey to cooperative society; this incurred certain cost of transportation ( $₹$ $6 / \mathrm{kg}$ ) hence is added to the marketing cost in this channel and it was ₹43 per kg of honey. But in the case of channel I, the village level trader would meet beekeepers to collect honey.

In the case of Channel III, the beekeeper has to spend more on processing, labor, and transportation because the food retail companies would expect good quality and beekeeper has to reach the procurement unit of the company. Hence, in this marketing channel, the beekeeper has to spend slightly more marketing costs than the channel I and Channel II but ultimately beekeeper would 
receive a same price. In final marketing channel, the beekeeper has to spend more marketing cost when compared to other channels because in this channel the beekeeper has to spend on packaging material and labeling cost and processing cost as well. Therefore in this channel, the marketing cost was highest and beekeeper sell directly to consumer hence, beekeeper receive higher prices than other channel

\section{Price spread in different marketing channels of honey marketing}

The producer share in consumer rupee was cent percent in the case of channel-IV. In this channel, the beekeeper sells honey directly to consumers hence it also called direct marketing and price spread in this marketing channel was zero. Followed by channel-II, the producer share in consumer rupee was 77.77 per cent. This indicates that cooperatives play a major role in the marketing and development of beekeepers in the study area. The producer share in consumer's rupee was lowest in the case of channel-III it was 63.63 percent when compared to other marketing channels due to its higher selling price to consumers and the price spread was ₹ 200 per $\mathrm{kg}$ of honey.

In conclusion, the marketing of honey in study area was highly unorganized and still farmer find some good markets in disposal of honey. in study area, Cooperatives play a major role in the marketing and development of honey production in the study area. The channel -II pertained to marketing of honey through Cooperative societies in which the producer share in consumer rupee was 77.77 per cent. The beekeeper has to spend more marketing costs on the channel -IV because packaging material and labeling was incurred by beekeeper only hence it would be higher marketing cost. The food retail companies spend more on marketing costs due to its intensive labor cost and transportation of honey from beekeepers to consumers. But cooperative societies spend more marketing costs on quality packaging material. Indian honey is having good international demand due to its special feature of medicinal flower nectar source hence engaging in exporting activities will widen marketing choices for beekeepers in study area.

\section{Acknowledgement}

Fervently and modestly, I extend my whole hearted gratitude and sincere thanks to Dr. D.H. Mitrannavar, Assistant Professor, Department of Agribusiness Management, College of Agriculture, University of Agricultural Sciences, Dharwad and Chairman of my Advisory Committee, for his invaluable guidance, constant encouragement, genuine cooperation and moral support throughout the study period, which enabled me to go through the ups and downs and complete my research successfully.

\section{References}

Anonymous, 2018, Export of natural honey from India 2017-18, www.apeda.gov.in

Avinash, H. S., 2011, An economic analysis of production and marketing of coffee in Chikmagalur district of Karnataka, M.Sc (Agri) Thesis, Univ. Agric. Sci., Dharwad. (India)

Belie, T., 2009, Honeybee Production and Marketing Systems, Constraints and Opportunities in Burie District of Amhara Region, Ethiopia, M.Sc (Agri) Thesis, Bahir Dar Univ., Ethiopia.

Garcia, N. L., 2018, The current situation on the international honey market, online article https://doi.org/10.1080/0005772X.2018 .1483814

Mehrotra, S., 2014, Production and 
Marketing of Honey in Samastipur District of Bihar-An Economic Analysis, M.Sc. (Agri), Thesis, The Rajendra Agric. Univ. (Bihar).

Norberto L. García., 2018, The current situation on the international honey market, Bee World,

Saner,G, Murat, Y., Sait E., Buket, K., and Figen, C., (2007) Alternative marketing strategies for honey and other bee products in Turkey, $J$ of Agril \& Food Information, 8(4), 65-74.
Srikanth, C. D. and Sowmya, K. S., 2014, Strategies for honey marketing in India, Popular Kheti, 2(4): 116-117.

Tarunika J. A., 2014, beekeeping industry in India: future potential, International $J$. Res. Appl., Nat. Soc. Sci.., 2(7), 133140

Vijay Kumar, V. and Gladstone Joy, N., 2017, Honey production and marketing - Overview, Int. J. Engi. and Management Res., (7)6 : 30-42.

\section{How to cite this article:}

Anil Kumar, K. and Mitrannavar, D. H. 2020. Disposal Pattern of Honey in Western Ghats of Karnataka, India. Int.J.Curr.Microbiol.App.Sci. 9(09): 2056-2063.

doi: https://doi.org/10.20546/ijcmas.2020.909.256 